\title{
IMPLEMENTASI LOGIKA FUZZY DENGAN MENGGUNAKAN METODE MAMDANI UNTUK MENENTUKAN PENERIMAAN BEASISWA DARI YAYASAN RUMAH ZAKAT
}

\author{
Nanda Jarti, S. Kom, M. Kom', Ramadan Febriansyah ${ }^{2}$ \\ Fakultas Teknik Universitas Putera Batam \\ email : nandaluthan@gmail.com \\ Submitted: 10-10-2017, Reviewed: 26-10-2017, Accepted 03-11-2017 \\ http://dx.doi.org/10.22202/jei.2017.v4i1.2699
}

\begin{abstract}
ABSTRAK
beasiswa adalah suatu bantuan pendidikan yang diberikan oleh suatu lembaga instansi ataupun non instansi, yang diberikan kepada siswa yang berprestasi ataupun kurang mampu guna untuk mendukung proses belajar siswa tersebut. Rumah zakat adalah salah satu lembaga yang memberikan bantuan sekolah atau beasiwa untuk para pelajar di kota Batam, untuk proses seleksinya, tidak ada cara khusus ataupun perhitungan matematis yang digunakan Rumah zakat untuk proses seleksinya, sehingga memungkinkan beasiswa tersebut tidak tepat sasaran. logika fuzzy Mamdani merupakan logika kabur dengan menggunakan metode Mamdani, yang fungsinya dapat di implementasikan dalam melakukan pengambilan keputusan, seperti menentukan seleksi penerima beasiswa, dengan diterapkannya logika fuzzy untuk proses seleksi penerima beasiswa, maka hasil yang didapat akan lebih tepat sasaran, karena proses yang dihasilkan berdasarkan perhitungan secara matematis.
\end{abstract}

Kata kunci: Beaiswa, Rumah zakat, logika fuzzy, mamdani

\begin{abstract}
the scholarship is an educational assistance provided by an institution or non agency, agencies that are given to students who are top achievers or less capable in order to support the students ' learning process. Rumah zakat is one of the agencies that provide assistance or scholarship for school students in Batam city, for this process, there is no special way or mathematical calculations used this process for Rumah zakat, thus allowing the scholarship is not right on target. Mamdani fuzzy logic is fuzzy logic by using a function, Mamdani method can be implemented in the decision-making, as do determine the selection of scholarship recipients, by implementing fuzzy logic for the selection process for the scholarship recipients, then the results obtained will be more precisely targeted, because the
\end{abstract}


process is generated based on calculation mathematically.

Keywords: Scholarship, Rumah zakat, fuzzy logic, mamdani

\section{PENDAHULUAN}

Perkembangan
Teknologi

Informasi saat ini mengalami kemajuan yang sangat signifikan setiap tahunnya, hal ini tidak terlepas dari munculnya ide-ide baru atau gagasan yang telah banyak menciptakan penemuan penemuan baru, baik itu dari segi Hardware (Perangkat Keras) maupun Software (perangkat lunak). Sebagian besar banyak perusahaan atau organisasi yang kini telah mengunakan atau menerapkan berbagai macam sistem dari Teknologi Informasi, seperti untuk penyeleksian penerima beasiswa. Meski demikian, masi banyak juga kita jumpai organisasi yang belum menerapkan Teknologi informasi secara maksimal, seperti salah satunya Rumah Zakat.Rumah zakat sendiri salah satu lembaga swadaya masyarakat yang ada di kota Batam, beralamatkan di Komplek Lotus Garden Blok A No.8 Kel. Teluk Tering, Kec. Batam Kota - Batam. Yang memfokuskan kerjanya pada pengelolaan zakat, infaq, shodaqoh dan wakaf. Selain menerima titipan zakat, Rumah Zakat sendiri memiliki program - program kerja seperti senyum Juara (Pendidikan), senyum sehat (Kesehatan) dan senyum mandiri (Kemandirian Kewirausahaan). Untuk senyum jauara sendiri, Rumah Zakat memiliki program beasiswa dengan sebutan beasiswa ceria untuk tingkat sekolah dasar, hingga ke jenjang perkuliahan.Untuk penyeleksian penerimaan beasiswa, Rumah Zakat sendiri melakukan seleksi berdasarkan dari data pendidikan siswa serta latar belakang keluarga siswa tersebut, seperti melihat dari nilai rata-rata terakhir, penghasilan perbulan orang tua serta jumlah tangungan orang tua calon penerima beasiswa tersebut. Hal ini tentu dapat menimbulkan kesenjangan atau masalah, seperti sulitnya untuk menentukan penerima beasiswa yang tepat, yang berakibat sering terjadinya ketidak tepatan penerima beasiswa, atau tidak tepat sasaran dan tentu saja hal ini dapat memperlambat proses penerimaan beasiswa, di karnakan kurang efektifnya metode penyelekseian yang digunakan. Sebenarnya masalah ini dapat diatasi apabila Rumah Zakat sudah mengunakan atau memanfaatkan Teknologi informasi dengan maksimal, seperti memanfaatkan Logika Fuzzy dengan metode Mamdani untuk penyeleksian penerima beasiswa tersebut.Dengan menggunakan logika fuzzy Mamdani, penyeleksi dapat membuat keputusan lebih adil dan manusiawi dalam menentukan penerima beasiswa di yayasan Rumah Zakat, di karnakan logika fuzzy 
sendiri dapat menunjukan sejauh mana suatu nilai itu bisa dikatakan benar, dan sejauh mana suatu nilai bisa dikatakan salah, berbeda dengan logika tradisional, yang hasilnya hanya berdasarkan, benar atau salah, selain itu logika fuzzy sendiri dapat membuat sistem lebih adaptif. Dengan di terapkannya logika fuzzy di rumah zakat, masalah masalah seperti ketidak tepatan penerima beasiswa dapat di atasi, serta hal ini juga dapat membuktikan bahwa logika fuzzy dapat diterapkan di berbagai bidang seperti pengambilan keputusan di dalam sebuah organisasi.Adapun perumusan masalahnya adalah: 1)Bagaimana melakukan seleksi penerimaan beasiswa dengan menggunakan Logika Fuzzy Mamdani ? 2)Bagaimana penerapan Logika Fuzzy Mamdani untuk membantu seleksi penerimaan beasiswa di Rumah zakat ? 3)Bagaimana implementasi seleksi penerimaan beasiswa dengan mengunakan metode Mamdani ?Adapun tujuan penelitian ini adalah: 1) Membantu Rumah zakat untuk menyeleksi penerimaan beasiswa dengan menggunakan Logika Fuzzy Mamdani. 2)Membantu Rumah zakat untuk penerapan logika Fuzzy Mamdani untuk seleksi penerimaan beasiswa di Rumah zakat. 3)Untuk membangun sistem pendukung keputusan yang handal dan efektif dalam seleksi penerimaan beasiswa.

\section{LANDASAN TEORI}

\section{Artificial Intelligence}

Artificial Intelligence atau kecerdasan buatan merupakan bidang ilmu komputer yang mempunyai peran penting di era ini dan masa akan datang. AI mencakup bidang yang cukup besar. Mulai dari yang paling umum hingga khusus. Dari learning atau perception hingga pada permainan catur, pembuktian teori matematika, menulis puisi, mengemudikan mobil dan melakukan diagnosa penyakit. AI merupakan sebuah ilmu yang universal. (Budihartono, 2014: 2) Menurut Naba (2009: 1) Fuzzy Logic adalah sebuah metode berhitung dengan variabel katakata (linguistic variable), sebagai peganti berhitung dengan bilangan. Kata-kata yang digunakan dalam fuzzy logic memang tidak sepresisi bilangan, namun kata-kata jauh lebih dekat dengan intuisi manusia. Dengn fuzzy logic, sistem kepakaran manusia bisa di implementasikan ke dalam bahasa mesin dengan mudah dan efisien.

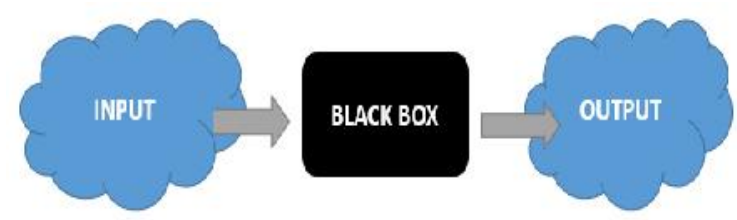

Gambar: 2.1 Model Black-Box

Sumber: Naba (2009: 3) 


\section{METODE PENELITIAN}

1. Identifikasi Masalah

Penulis akan mengindentifikasi dan menguraikan masalah dari variabel yang diteliti, dengan cara mengumpulkan data, lalu di identifikasi, sehingga diperolehlah gambaran dari masalah yang akan diteliti.

2. Analisis Ruang Lingkup

Selanjutnya dengan membantasi ruang lingkup, yang bertujuan agar penelitian ini lebih terarah dan hasilnya tidak menyimpang dari apa yang di harapkan.

3. Studi Literatur

Dalam proses ini akan dicari sumber atau informasi yang berhubungan dengan judul penelitian yang penulis ambil. Pencarian informasi atau sumber yang berhubungan dengan penelitian akan dilakukan lewat buku-buku dan jurnal ilmiah. Adapun studi yang akan penulis pelajari guna untuk mendukung proses penelitian antara lain seperti:

\section{a. Logika Fuzzy}

Penulis akan mempelajari tentang Logika fuzzy yang nantinya akan digunakan untuk mengantikan cara penyeleksian penerima beasiswa di rumah zakat, yang saat ini masi mengunakan cara konvensional atau tradisional.

b. FIS Mamdani

Untuk metode atau Fuzzy

Inference systemnya, disini penulis menggunakan metode Mamdani.

c. Beasiswa

Disini penulis juga akan mempelajari tentang beasiswa, guna untuk menunjang proses dari penelitian ini.

4. Pengumpulan data

Tahap selanjutnya, penulis akan melakukan pengumpulan data yang nantinya data tersebut akan di olah, yang berguna untuk menunjang proses penelitian ini.

5. Pengolahan data (Matlab 6.1)

Setelah semua data yang diperlukan terkumpul, penulis akan menggolah data tersebut untuk di proses menggunakan program aplikasi Matlab.

6. Implementasi Sistem

Setelah semua proses dilakukan, sistem yang dibuat akan di implementasikan guna untuk membantu Yayasan Rumah zakat untuk melakukan penarikan kesimpulan seleksi penerimaan beasiswa.

7. Kesimpulan

Terakhir, adapun hasil atau output dari penelitian ini adalah beruapa 
keputusan yang lebih efektif, layak atau tidak layaknya seseorang untuk memperoleh beasiswa.

\section{Operasional Variabel}

Operasional variabel merupakan suatu cara dimana setiap variabel input didefinisikan atau di tentukan himpunan fuzzy nya, sebelum nantinya setiap variabel input dimasukan dan diproses di Matlab.

Adapun yang dimaksud dengan operasional variabel dalam penelitian adalah sebagai berikut:

1. Nilai rata-rata terakhir

Calon penerima beasiswa akan diseleksi berdasarkan nilai atau IPK nya, biasanya, nilai atau IPK tertinggi akan memperoleh kesempatan besar dalam

penerimaan beasiswa.Operasional variabel dari Nilai/IPK terakhir: "Sangat baik", "Baik", "Cukup", "Kurang".

2. Penghasilan orang tua perbulan

Calon penerima beasiswa akan diseleksi berdasarkan penghasilan orang tua perbulan, biasanya cara ini ditujukan untuk kalangan kurang mampu. Dan dimana penghasilan terkecil akan mendapat kesempatan terbesar untuk memperoleh beasiswa.Operasional variabek dari Penghasilan orang tua perbulan: "Sangat layak", "Layak", "Cukup layak", "Tidak layak".
Calon penerima beasiswa akan diseleksi berdasarkan jumlah tanggungan orang tua, sama halnya dengan poin sebelumnya, biasanya cara ini ditujukan untuk kalangan kurang mampu. Dan biasanya jumlah tanggungan terbanyak didalam keluarga akan lebih berpeluang dalam memperoleh beasiswa.Operasional variabel dari Jumlah tanggungan orang tua: "Sangat banyak", "Banyak", "Cukup banyak", "Sedikit".

\section{HASIL PENELITIAN DAN PEMBAHASAN}

\section{Analisa aliran fuzzy}

Analisis aliran fuzzy dalam penelitian ini diawali dengan memasukan tiga variabel input yang masing-masingnya memiliki empat himpunan fuzzy, dan satu variabel output dengan tiga himpunan fuzzy. Langkah selanjutnya yaitu memasukkan data kedalam aplikasi Matlab. Berikut ini merupakan alur dari Logika fuzzy dalam penelitian ini:

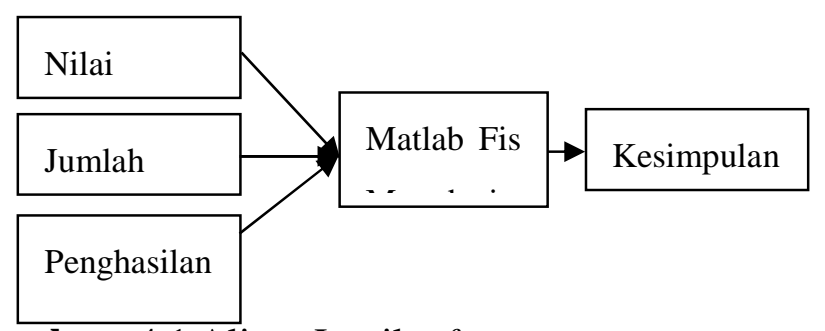

Gambar: 4.1 Aliran Logika fuzzy

Sumber: Data Olahan

3. Jumlah tanggungan orang tua 


\section{Fuzzyfication}

Setelah menetapkan aliran fuzzy, input dan jumpah himpunan fuzzy dari masing-masing input, selanjutnya menentukan semesta pembiraan dari masing-masing himpunan, berikut ini didefinisikan dalam bentuk tabel.

Tabel: 4.2 Semesta Pembicaraan

\begin{tabular}{|c|c|c|}
\hline \multirow[t]{3}{*}{ Input } & Nama Varıabel & Semesta Pembicaraan \\
\hline & Nilai & {$[0-100]$} \\
\hline & $\begin{array}{l}\text { Jumlah Tanggiıngan } \\
\text { Penghasilen partulan }\end{array}$ & $\begin{array}{l}{[1-1 \hat{i}]} \\
{[0-2700]}\end{array}$ \\
\hline \multirow[t]{4}{*}{ Output } & Keputusan & \multirow[b]{2}{*}[0-25-50]{} \\
\hline & Tidak layal. & \\
\hline & Ragu-ragu & 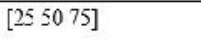 \\
\hline & Layak & {$\left[\begin{array}{lllll}30 & 75 & 100\end{array}\right]$} \\
\hline
\end{tabular}

1. Fungsi derajat keanggotan Variabel Nilai

Variabel Nilai terdiri dari 4 himpunan fuzzy, yang terdiri dari (Kurang, cukup, baik dan sangat baik). Berikut ini merupakan variabel Nilai yang di definisikan dalam sebuah tabel.

Tebel: 4.3 Himpunan fuzzy Variabel Nilai

\begin{tabular}{|c|c|c|c|}
\hline \multicolumn{1}{|c|}{ Semesta } & IIimpunan & Domain & Parameter \\
\hline$[0-100]$ & & & \\
& kurang & {$[0-60]$} & {$\left[\begin{array}{llll}0 & 5 & 5 & 60\end{array}\right]$} \\
& cukup & {$[50-70]$} & {$\left[\begin{array}{lll}50 & 60 & 70\end{array}\right]$} \\
\cline { 2 - 4 } & Baik & {$\left[\begin{array}{lll}60 & 80\end{array}\right]$} & {$\left[\begin{array}{lll}60 & 70 & 80\end{array}\right]$} \\
\cline { 2 - 4 } & Sangat baik & {$[70-100]$} & {$\left[\begin{array}{llll}70 & 80 & 100 & 100\end{array}\right]$} \\
\hline
\end{tabular}

Berdasarkan tabel 4.3 diatas, dapat dilih at terdapat 4 himpunan fuzzy dengan se mesta pembicaraan [0-100] yang terdiri dari himpunan fuzzy "Kurang" dengan Domain [0-60] dan parameter [0 $\begin{array}{llll}0 & 0 & 50 & 6\end{array}$ 0], "Cukup" dengan Domain [50-70] da n parameter [50 6070], "Baik" dengan Domain [60-80] dan parameter [60 708 0] dan "Sangat baik" dengan Domain [ 70-100] dan parameter [l] $\begin{array}{llll}70 & 80 & 100 & 100 .\end{array}$ Berikut ini merupakan tampilan himpuna n fuzzy dengan Variabel Nilai dalam be ntuk Matlab

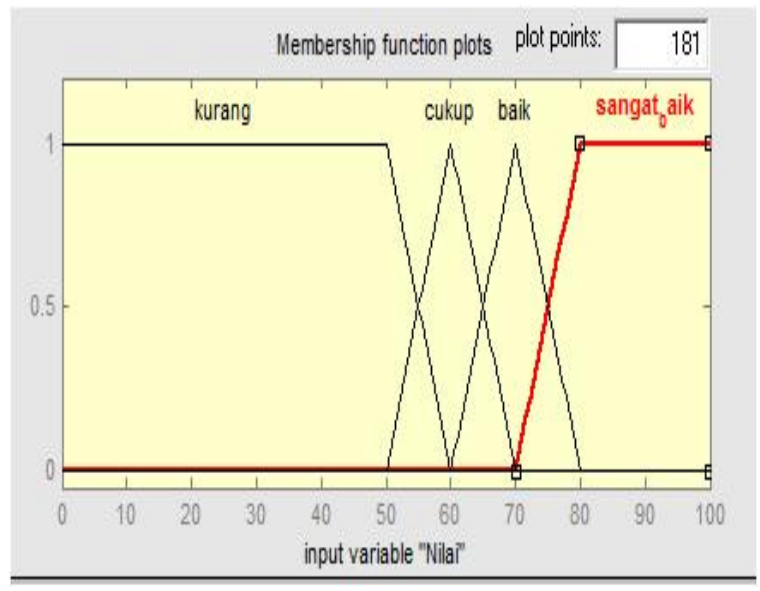

Gambar: 4.2 Himpunan fuzzy Variabel Nilai

Sumber: Matlab 6.1

Untuk himpunan fuzzy "Kurang" a dapun representasi linier yang digunakan yaitu Kurva trapesium, dengan domain [0-60] dan parameter [0 $\left.0 \begin{array}{lll}0 & 50 & 60\end{array}\right]$. Ber ikut ini merupakan bentuk umum dari $\mathrm{h}$ impunan fuzzy "Kurang". 


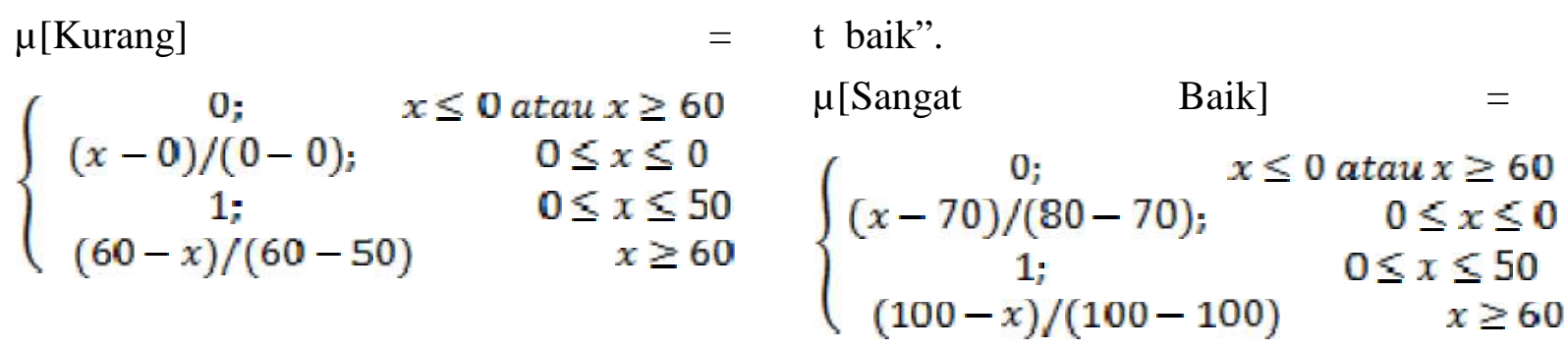

Berikutnya Untuk himpunan fuzzy "Cukup" adapun representasi linier yang digunakan yaitu Kurva Segitiga, denga n domain [50-70] dan parameter [50 60 70]. Berikut ini merupakan bentuk um um dari himpunan fuzzy "Cukup". $\mu[$ Cukup] $\left\{\begin{array}{cc}0 ; & x \leq 50 \text { atau } x \geq 70 \\ (x-50) /(60-50) ; & 50 \leq x \leq 60 \\ (60-x) /(70-60) ; & 60 \leq x \leq 70\end{array}\right.$

Selanjutnya Untuk himpunan fuzzy "Baik" adapun representasi linier yang digunakan yaitu Kurva Segitiga, dengan domain [60-80] dan parameter [60 70 80]. Berikut ini merupakan bentuk umu m dari himpunan fuzzy "Baik". $\mu$ [Baik]
$\left\{\begin{array}{cr}0 ; & x \leq 60 \text { atau } x \geq 80 \\ (x-60) /(70-60) ; & 60 \leq x \leq 70 \\ (70-x) /(80-70) ; & 70 \leq x \leq 80\end{array}\right.$

Dan Untuk himpunan fuzzy "Sanga t baik" adapun representasi linier yang digunakan yaitu Kurva Trapesium, deng an domain [70-100] dan parameter [70 80100 100]. Berikut ini merupakan be ntuk umum dari himpunan fuzzy "Sanga
Selanjutnya, untuk perhitungan manual untuk menentukan nilai dari tiap -tiap himpunan fuzzy adalah sebagai beri kut. Di ketahui Nilai dari Siswi SMP 2 9 Batu ampar dengan nama Nur Anisya h yaitu sebesar 68.05. Nilai 68.05 sendi ri masuk diantara himpunan "Cukup" da n "Baik". Untuk mengetahui bobot him punan fuzzy dari Nilai adalah sebagai $\mathrm{b}$ eriut.

a. Himpunan Fuzzy Nilai " $\mu$ [Cukup]"

$$
\begin{aligned}
& \mu[\text { Cukup }]=(\mathrm{x}-\mathrm{a}) /(\mathrm{b}-\mathrm{a}) \\
& \frac{(68.05-60)}{(70-60)}=8.05 \\
& =0.8
\end{aligned}
$$

b. Himpunan Fuzzy Nilai " $\mu$ [Baik]”

$$
\begin{aligned}
& \mu[\text { Baik }]=(b-x) /(c-b) \\
& (70-68.05)=1.05 \\
& \overline{(80-70)}=\overline{10} \\
& =0.1
\end{aligned}
$$

2. Fungsi derajat keanggotaan variabel Jumlah tanggungan

Variabel ini terdiri dari empat him punan fuzzy, yaitu sedikit, cukup banyak , banyak, dan sangat banyak. Berikut in i di definisikan dalam bentuk tabel. 
Tabel: 4.4 Himpunan fuzzy variabel Jum lah tanggungan

\begin{tabular}{|c|c|c|c|}
\hline $\begin{array}{l}\text { Semesta } \\
\text { Pembicaraa }\end{array}$ & Himpunan & Domain & Parameter \\
\hline \multirow[t]{4}{*}[1-13]{} & Sedikit & {$[0-3]$} & {$\left[\begin{array}{llll}0 & 0 & 1 & 3\end{array}\right]$} \\
\hline & Cukup banyak & [1-5] & {$\left[\begin{array}{lll}1 & 3 & 5\end{array}\right]$} \\
\hline & Banyak & [3-7] & {$\left[\begin{array}{lll}3 & 5 & 7\end{array}\right]$} \\
\hline & Sangat banyak & [5-13] & {$\left[\begin{array}{llll}5 & 7 & 13 & 13\end{array}\right]$} \\
\hline
\end{tabular}

Berdasarkan tabel 4.4 diatas, dapat dilihat terdapat 4 himpunan fuzzy deng an semesta pembicaraan [1-13] yang ter diri dari himpunan fuzzy "Sedikit" deng an Domain [0-3] dan parameter [0 $\begin{array}{lll}0 & 0 & 1\end{array}$ 3], "Cukup banyak" dengan Domain [15] dan parameter [ $\left[\begin{array}{lll}1 & 3 & 5\end{array}\right]$, "Baik" denga n Domain [3-7] dan parameter [3 5 5 7] dan "Sangat baik" dengan Domain [5-1 3] dan parameter [ [ $\left.\begin{array}{llll}5 & 7 & 13 & 13\end{array}\right]$

Berikut ini merupakan tampilan $\mathrm{h}$ impunan fuzzy dengan Variabel Jumlah $\mathrm{t}$ anggungan dalam bentuk Matlab

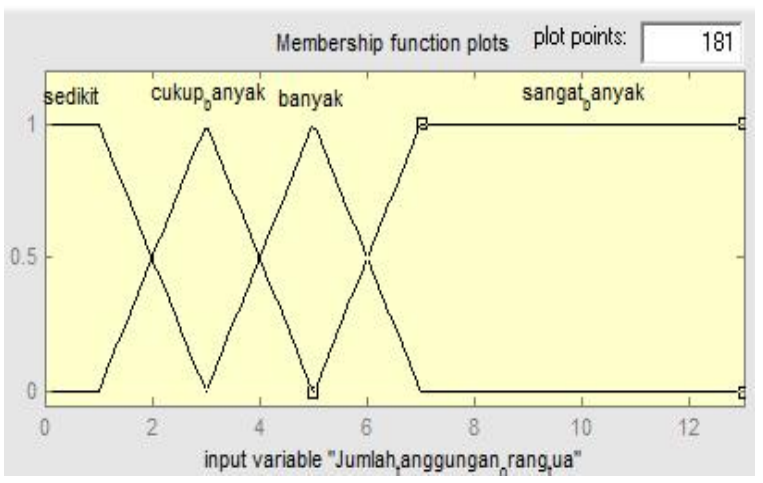

Gambar: 4.3 Himpunan fuzzy variabel j umlah tanggungan

Sumber: Matlab 6.1
Untuk himpunan fuzzy "Sedikit" adapun representasi linier yang digunakan yaitu Kurva trapesium, dengan domain [0-3] dan parameter [ $\left[\begin{array}{llll}0 & 0 & 1 & 3\end{array}\right]$. Berikut ini merupakan bentuk umum dari himpunan fuzzy "Sedikit". $\mu[$ Sedikit $]$

$$
\left\{\begin{array}{cr}
0 ; & x \leq 0 \text { atau } x \geq 3 \\
(x-0) /(0-0) ; & 0 \leq x \leq 0 \\
1 ; & 0 \leq x \leq 1 \\
(3-x) /(3-1) & x \geq 3
\end{array}\right.
$$

Berikutnya Untuk himpunan fuzzy "Cukup banyak" adapun representasi lini er yang digunakan yaitu Kurva Segitiga, dengan domain [1-5] dan parameter [1 3 5]. Berikut ini merupakan bentuk u mum dari himpunan fuzzy "Cukup bany ak".

$\mu[$ Cukup banyak $]$ =

$$
\left\{\begin{array}{cc}
0 ; & x \leq 1 \text { atau } x \geq 5 \\
(x-1) /(3-1) ; & 1 \leq x \leq 3 \\
(3-x) /(5-3) ; & 3 \leq x \leq 5
\end{array}\right.
$$

Selanjutnya Untuk himpunan fuzzy "Banyak" adapun representasi linier ya ng digunakan yaitu Kurva Segitiga, den gan domain [3-7] dan parameter [3 557 ]. Berikut ini merupakan bentuk umum dari himpunan fuzzy "Banyak".

$\mu[$ Banyak $]$

$$
\left\{\begin{array}{cc}
0 ; & x \leq 3 \text { atau } x \geq 7 \\
(x-3) /(5-3) ; & 3 \leq x \leq 5 \\
(5-x) /(7-5) ; & 5 \leq x \leq 7
\end{array}\right.
$$


Dan Untuk himpunan fuzzy "Sanga t banyak" adapun representasi linier yan g digunakan yaitu Kurva Trapesium, de ngan domain [5-13] dan parameter [5 7 13 13]. Berikut ini merupakan bentuk umum dari himpunan fuzzy "Sangat ban yak".

$$
\begin{aligned}
& \mu\left[\text { Sangat } \begin{array}{cr}
\text { banyak }] & = \\
0 ; & x \leq 5 \text { atau } x \geq 13
\end{array}\right. \\
& \left\{\begin{array}{cr}
(x-5) /(7-5) ; & 5 \leq x \leq 7 \\
1 ; & 7 \leq x \leq 13 \\
(13-x) /(13-13) & x \geq 13
\end{array}\right.
\end{aligned}
$$

Selanjutnya, untuk perhitungan manual untuk menentukan nilai dari tiap -tiap himpunan fuzzy adalah sebagai beri kut. Di ketahui Jumlah tanggungan oran g tua dari Siswi SMP 29 Batu ampar d engan nama Nur Anisyah yaitu sebanya k 5. Nilai 5 sendiri masuk diantara him punan "Cukup banyak" , "Banyak" dan "Sangat Banyak" Untuk mengetahui bo bot himpunan fuzzy dari Jumlah tanggun gan orang tua adalah sebagai beriut.

a. Himpunan Fuzzy Jumlah tanggungan " $\mu$ [Cukup Banyak]"

$$
\mu[\text { Cukup Banyak }]=0
$$

b. Himpunan Fuzzy Jumlah tanggungan

$$
\begin{aligned}
& \text { " } \mu \text { Banyak]" } \\
& \mu[\text { Banyak }]=(x-a) /(b-a) \\
& (5-3)=2 \\
& \frac{(5-3)=}{2} \\
& =1
\end{aligned}
$$

c. Himpunan Fuzzy Jumlah tanggungan " $\mu$ [Sangat Banyak]" $\mu[$ Sangat Banyak $]=(x-a) /(b-$ a)

$$
\begin{aligned}
& \frac{(5-5)}{(7-5)}=\frac{0}{2} \\
& =0
\end{aligned}
$$

3. Fungsi derajat keanggotaan variabel Penghasilan perbulan

Variabel ini terdiri dari empat him punan fuzzy, yaitu kurang, cukup banya $\mathrm{k}$, banyak, dan sangat banyak. Berikut i ni di definisikan dalam bentuk tabel.

Tabel: 4.5 Himpunan fuzzy variabel Pen ghasilan perbulan

\begin{tabular}{|c|c|c|c|}
\hline \multicolumn{1}{|c|}{ Semesta } & Himpunan & Domain & Parameter \\
\hline Perbicaraan & & & \\
\hline$[0-2700]$ & Kurang & {$[0-1000]$} & {$[005001000]$} \\
\cline { 2 - 5 } & Cukup banyak & {$[500-1500]$} & {$[5001000$ 1500] } \\
\cline { 2 - 4 } & Banyak & {$[1000-2000]$} & {$[100015002000]$} \\
\cline { 2 - 4 } & Sangat banyak & {$[1500-2700]$} & {$[1500200027002700]$} \\
\hline
\end{tabular}

Berdasarkan tabel 4.5 diatas, dapat dilihat terdapat 4 himpunan fuzzy deng an semesta pembicaraan [0-2700] yang $t$ erdiri dari himpunan fuzzy "Kurang" de ngan Domain [0-1000] dan parameter [0 0500 1000], "Cukup banyak" dengan Domain [500-1500] dan parameter [500 1000 1500], "Baik" dengan Domain [10 
00-2000] dan parameter [1000 1500200 0] dan "Sangat baik" dengan Domain [ 1500-2700] dan parameter [1500 20002 700 2700].

Berikut ini merupakan tampilan hi mpunan fuzzy dengan Variabel dalam b entuk Matlab

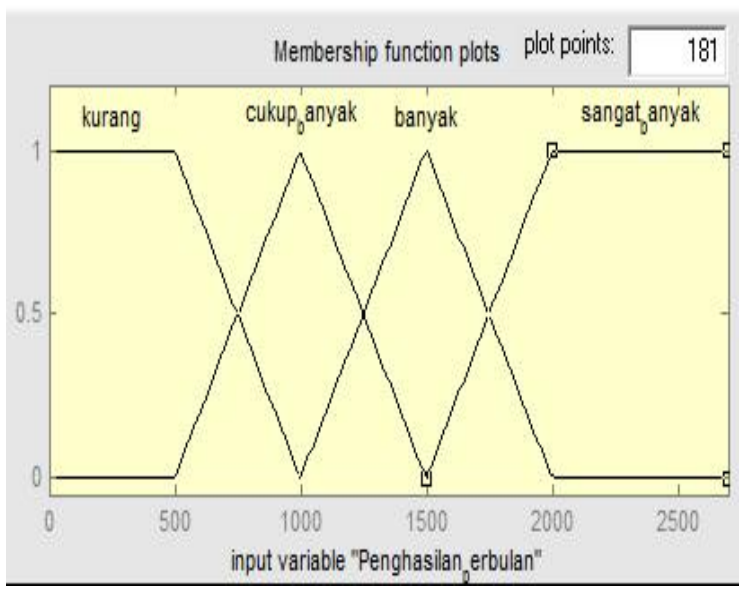

Gambar: 4.4 Himpunan fuzzy variabel Penghasilan perbulan

Sumber: Matlab 6.1

Untuk himpunan fuzzy "Kurang" a dapun representasi linier yang digunakan yaitu Kurva trapesium, dengan domain [0-1000] dan parameter $\left[\begin{array}{llll}0 & 0 & 500 & 1000\end{array}\right.$

]. Berikut ini merupakan bentuk umum dari himpunan fuzzy "Kurang". $\mu[$ Kurang]

$$
\left\{\begin{array}{crl}
0 ; & x \leq 0 \text { atau } x & \geq 1000 \\
(x-0) /(0-0) ; & & 0 \leq x \leq 0 \\
1_{i} & & \leq x \leq 500 \\
(1000-x) /(1000-500) & x \geq 100
\end{array}\right.
$$

Berikutnya Untuk himpunan fuzzy "Cukup banyak" adapun representasi lini er yang digunakan yaitu Kurva Segitiga, dengan domain [500-1500] dan parame ter [500 1000 1500]. Berikut ini merup akan bentuk umum dari himpunan fuzzy

"Cukup banyak".

$$
\begin{aligned}
& \mu[\text { Cukup } \quad \text { banyak }] \\
& \left\{\begin{array}{cc}
0 ; & x \leq 500 \text { atau } x \geq 1500 \\
(x-500) /(1000-500) ; & 500 \leq x \leq 1000 \\
(1000-x) /(1500-1000) ; & 1000 \leq x \leq 1500
\end{array}\right.
\end{aligned}
$$

Selanjutnya Untuk himpunan fuzzy "Banyak" adapun representasi linier ya ng digunakan yaitu Kurva Segitiga, den gan domain [1000-2000] dan parameter [1000 1500 2000]. Berikut ini merupaka $\mathrm{n}$ bentuk umum dari himpunan fuzzy " $\mathrm{B}$ anyak".

$\mu[$ Banyak $]$$$
\int \quad 0 ; \quad x \leq 1000 \text { atau } x \geq 2000
$$$$
\{(x-1000) /(1500-1000) ; \quad 1000 \leq x \leq 1500
$$$$
(1500-x) /(2000-1500) ; \quad 1500 \leq x \leq 2000
$$

Dan Untuk himpunan fuzzy "Sanga t banyak" adapun representasi linier yan g digunakan yaitu Kurva Trapesium, de ngan domain [1500-2700] dan parameter [1500 20002700 2700]. Berikut ini m erupakan bentuk umum dari himpunan $f$ uzzy "Sangat banyak".

$\mu$ [Sangat banyak $]$ = 


$$
\left\{\begin{array}{cr}
0 ; & x \leq 1500 \text { atau } x \geq 2700 \\
(x-1500) /(2000-1500) ; & 1500 \leq x \leq 2000 \\
1 ; & 2000 \leq x \leq 2700 \\
(2700-x) /(2700-2700) & x \geq 2700
\end{array}\right.
$$

Selanjutnya, untuk perhitungan ma nual untuk menentukan nilai dari tiap-ti ap himpunan fuzzy adalah sebagai berik ut. Di ketahui Jumlah Penghasilan perbu lan orang tua dari Siswi SMP 29 Batu ampar dengan nama Nur Anisyah yaitu sebanyak 1000 (Rp.1000.000). Nilai 100 0 sendiri masuk diantara himpunan "Ku rang", "Cukup Banyak" dan "Banyak" Untuk mengetahui bobot himpunan fuzzy dari Jumlah Penghasilan perbulan oran $\mathrm{g}$ tua adalah sebagai beriut.

a. Himpunan Fuzzy Jumlah Penghasilan perbulan " $\mu[$ Kurang]"

$\mu[$ Kurang $]=(\mathrm{d}-\mathrm{x}) /(\mathrm{d}-\mathrm{c})$

$\frac{(1000-1000)}{(1000-500)}=\frac{0}{500}$

$=0$

b. Himpunan Fuzzy Jumlah Penghasilan perbulan " $\mu$ [Cukup Banyak]"

$\mu[$ Cukup Banyak] $(\mathrm{x}-\mathrm{a}) /(\mathrm{b}-\mathrm{a}$ )

$$
\begin{aligned}
& \frac{(1000-500)=}{500} \\
& (1000-500)= \\
& =1
\end{aligned}
$$

c. Himpunan Fuzzy Jumlah Penghasilan perbulan " $\mu[$ Banyak]" $(b-x) /(c-b)$

$$
\begin{aligned}
& \frac{(1500-1000)=}{}=\frac{500}{500} \\
& (2000-1500)= \\
& =1
\end{aligned}
$$

4. Fungsi derajat keanggotaan variabel Keputusan (Output)

Variabel ini terdiri dari 4 himpuna n, yaitu "tidak layak", "cukup laya k", "layak" dan "sangat layak", be rikut di definisikan dalam bantuk $\mathrm{t}$ abel.

Tabel: 4.6 Himpunan fuzzy variabel Kep utusan (output)

\begin{tabular}{|l|cc|c|}
\hline \multicolumn{1}{|c|}{ Semesta } & Himpunan & Domain & Parameter \\
Pembicaraan & & & \\
\hline$[0-100]$ & Tidak layak & {$[0-50]$} & {$[02550]$} \\
\cline { 2 - 4 } & Ragu-ragu & {$[25-75]$} & {$[255075]$} \\
\cline { 2 - 4 } & Layak & {$[50-100]$} & {$\left[\begin{array}{lll}50 & 75 & 100\end{array}\right]$} \\
\hline
\end{tabular}

Berdasarkan tabel 4.6 diatas, dapat dilih at terdapat 3 himpunan fuzzy dengan se mesta pembicaraan [0-100] yang terdiri dari himpunan fuzzy "Tidak layak" deng an Domain [0-50] dan parameter [0 25 50], "Ragu-ragu" dengan Domain [25-75 ] dan parameter [25 50 75] dan"Layak" dengan Domain [50-100] dan paramete r [ [50 75 100].

Berikut ini merupakan tampilan hi mpunan fuzzy dengan Variabel dalam b entuk Matlab. 


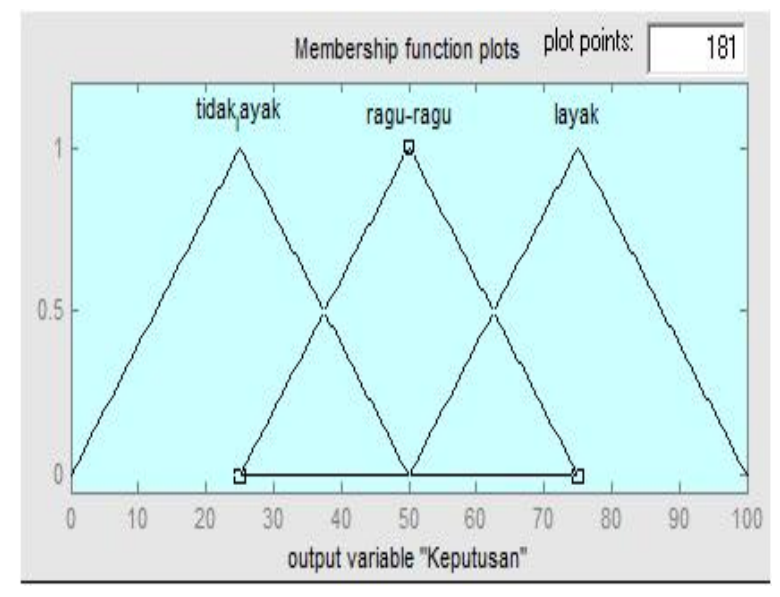

Gambar: 4.5 Himpunan Fuzzy Variabel

Keputusan (Output)

Sumber: Matlab 6.1

\section{SIMPULAN}

Berdasarkan penelitian yang dilakukan, adapun kesimpulan yang diambil adalah sebagai berikut:

1. Fuzzy Logic Mamdani dapat diterapkan untuk seleksi penerimaan beasiswa di yayasan Rumah zakat

2. Hasil perhitungan manual dan menggunakan Matlab, menggalamai perbedaan hasil, tetapi tetap bisa digunakan untuk penarikan kesimpulan, di karnakan setiap hasil perhitungan manual, tetap berada di domain yang tepat pada Matlab

3. Dari data keseluruhan, terdapat 3 siswa yang benar-benar layak untuk menerima beasiswa, 5 siswa yang tidak layak untuk menerima, dan selebihnya sebanyak 22 siswa yang masuk kedalam kriteria ragu-ragu.

\section{DAFTAR PUSTAKA}

Zamroni, (2014). Pemanfaatan Metode Logic Mamdani Untuk SPK Penerimaan Beasiswa di SMA Muhammadiyah 10 Sugio, Teknik Informatika. 1 (6): 561.

Putra and Hardiyanti, (2011). Penentuan Penerimaan Beasiswa Dengan Menggunakan Fuzzy Multiple Atribute Decission Making, Sistem Informasi. 1 (3): 287-288.

Adawiyah and Ruliah, (2013). Sistem Pendukung Keputusan Pemilihan Penerima Beasiswa Berbasis Fuzzy Mamdani, Sistem Informasi. 1 (9): 900-901.

Budihartono, W. and D. Suhartono. (2014).

ARTIFICIAL INTELLIGENCE

Konsep dan Penerapannya. ANDI. Yogyakarta.

Suyanto. (2014). Artificial Intelligence,

Searching-Reasoning-Planing-

Learning. Edisi ke 2. Informatika. Yogyakarta.

Kusumadewi, S. and S. Hartati. (2010).

Neuro-Fuzzy: Integrasi Sistem Fuzzy

\& Jaringan Syaraf. Edisi ke 2. GRAHA ILMU. Yogyakarta.

Kusumadewi, S. and H. Purnomo. (2013). APLIKASI LOGKA FUZZY Untuk Pendukung Keputusan. Edisi ke 2. GRAHA ILMU. Yogyakarta. 
Agus Naba. (2009). Belajar Cepat Fuzzy

Logic Menggunakan Matlab. ANDI. Yogyakarta.

Alifia. (2015). Negara Pemberi Beasiswa. PT Gramedia Widiasarana Indonesia. Jakarta
Sugiyono. (2014). Metode Penelitian Kuantitatif, Kualitatif dan $R \& D$. Edisi 20. ALFABETA, CV. Bandung.

Juliansyah Noor. (2011). Metodelogi Penelitian : Skripsi, Tesis, Disertasi, dan Karya Ilmiah. Edisi Peratama. KENCANA PRENADA MEDIA GRUP. Jakarta. 